\title{
トイレにおけるゼロ・エネルギー照明システムに関する研究
}

エネルギー・ハーベスティング技術を使った ZET 照明システムの実建物への実装

\section{STUDY ON ENERGY ZERO BALANCE BASED LIGHTING SYSTEM IN TOILET}

ZET lighting system using the energy harvesting technology implement to actual building

\section{石井久史 ${ }^{* 1}$, 藤山真美子 ${ }^{* 2}$, 小林 光*3, 石田壽一 ${ }^{* 4}$ \\ Hisashi ISHII, Mamiko FUJIYAMA, Hikaru KOBAYASHI and Toshikazu ISHIDA}

\begin{abstract}
In this research, the relationship between the possibility of zero balance of energy and the excretion were confirmed based on the data obtained from the demonstration experiment of ZET system. In the windowless the gents' toilet, found that the zero balance of energy could be achieved by reducing energy used for the behavior of needless excretion and wrong detection of lighting. The energy loss due to the lighting of unnecessary area for the excretion accounts for 2.8 to $15.7 \%$. In parametric study, one with the daylight window has surplus capacity from 1.65 to 3.65 times comparing to windowless one.
\end{abstract}

Keywords : Energy harvesting, Energy Zero Balance, Zero Energy Toilet (ZET), Business Continuity Planning at Ordinary Time, Hydroelectric Power, Behavior Pattern at Toilet, ハーベスティング，エネルギーゼロバランス，ゼロ・エネルギー・トイレ(ZET), 常時 BCP，水力発電，トイレの行動パターン

\section{1. 序}

自然災害は, 時として国民の生命や財産に大きな被害をもたらす。 前の東日本大震災では，建築物の倒壞や損傷，震災直後の火災や津 波などによって甚大な被害を受けた 1)。震災には，直接的な被害と は別に震災直後から復旧に向けた間に起こる二次的被害がある。二 次的被害は，避難先の衛生状態が悪化し発症する感染症や自ら水分 補給を抑制することに起因する血栓症等が挙げられる ${ }^{2)}$. すなわち, トイレ環境の悪化は, 臭気や使い難さだけの問題ではなく, 生死に かかわる問題となり得る。 そのため，災害時には，このリスクを軽 減する必要がある, 現状では, 主な対処法として仮設トイレの設置 が行われている。しかしながら，被災地に仮設トイレが行き渡るま で 4 日以上を要した自治体が $66 \%$ を占め ${ }^{3)}$, タイムリーに対応しき れているとは限らない。このような状況では, 避難所や防災拠点が 十分に機能を果たすことは難しく, 被災初期から機能できるトイレ 環境作りが久かせない，災害時にトイレで想定される懸念事は，臭 気, 污損, 暗い, 恐い, 寒い, 数が少ない, 段差, 設置場所が遠い, 男女共用およびプライバシーがない等であり，物理的機能による充 足と精神的プレッシャーによる負担の双方に影響を及ぼす。これら を予防するには, 使い難さの解消や常用トイレの罙長性の担保が肝

\footnotetext{
*1 株) LIXIL Technology Research 本部先端技術研究所 主任研究員・博士 (工学)

*2 東北大学大学院工学研究科都市建築学専攻 助教 ·博士 (工学)

*3 東北大学大学院工学研究科都市建築学専攻 准教授. 博士 (工学)

*4 東北大学大学院工学研究科都市建築学専攻 教授 ·博士 (工学)
}

要であると考える，例えば，污損，暗いおよび恐いに対しては，暗 所で見え難いことの解消がある，また，寒い，数が少ない，段差，設 置場所が遠い，男女共用およびプライバシーがない等に対しては， 普段から使い慣れた建物内既設トイレの活用が望ましい.

一方，災害時における建物内トイレは，衛生状態が極めて厳しい 状況にあることが報告 4 )されている，災害発生後のトイレは，系統 電力や設備運転用電力の途絶など使い難さが助長される．一般的に トイレには, Fig.1 に示寸様々な機器が設置されている，災害時な ぞに最低限トイレ機能を維持するには，明るさ，換気および水が必 要である，換気は建築的に空で対処でき，洗浄水は外部から供給で きるが，明るさは昼夜を問わず必要なため，空だけでは不十分とな る. 東日本大震災で被災した東北大学工学部, 同大大学院工学研究 科青葉山キャンパスの事例 5)では, 災害時の停電により, 洗浄用水 は敷地内の池から人力で供給できたが，視環境の確保には対処しき れなかった，その結果，衛生状態の悪化を一部で体感した，そのよ うな体験から，災害時の停電状況下ではトイレ空間を綺麗に使おう としても薄暗さからの使い難さによりトイレ内の污れが増大してい くという仮説を立て要因を絞り込んだ。そこで，本研究では，災害 時に大学や公共施設および一般事務所ビルなど, 一定規模以上の建

Senior Research Scientist, Advanced Technology Laboratory, Technology Research Division, LIXIL Corporation, Ph.D.

Assist. Prof., Dept. of Urban and Architecture, Graduate School of Engineering, TOHOKU University, Ph.D.

Assoc. Prof., Dept. of Urban and Architecture, Graduate School of Engineering, TOHOKU University, Ph.D.

Prof., Dept. of Urban and Architecture, Graduate School of Engineering, TOHOKU University, Ph.D. 
築物に設置されるトイレの視環境維持に必要な照明関連エネルギー について, 平時に上水道圧からエネルギー・ハーベスティングを行 い，そこで得られたエネルギーが常時非常時を問わずトイレ内照明 消費電力を賄うことだけに焦点を充てた。このシステムをゼロ・エ ネルギー・トイレ (ZET : Zero Energy Toilet) 照明システムと呼ぶ. ZET 照明システムは, 普段から使い慣れた災害時トイレという概念 の元, 災害時における地域防災拠点の業務継続および避難環境維持 を円滑にすると共に建築のゼロエネ化に貢献することも目的として いる. ここで対象とする非常時とは, 下記の状況を想定している.

1）上下水道が使える状況(損傷が小)でありながら電源復旧の遅れ や計画停電のような状況でトイレ使用が出来ない状態.

2) 自家発電設備が稼働しているが基幹電源だけに供給され, トイレ 照明用電源は供給されず使用困難となる状態.

どちらも上下水道に大規模損壊がなく, 事業継続性が可能であり ながら，トイレ環境として不便な状況を想定したものである。

以上より, 本研究では, 水道圧から発電した電力を蓄え, 常時非 常時におけるトイレ内照明電源等(Fig.1 ロが対象)のゼロバランス に向けたシステムを構築するための実証研究を東北大学大学院工学 研究科人間・環境系研究棟(2014 年竣工)にて試みた。本報では, 実 証実験にて取得したデータから, 照明エネルギーのゼロバランスに おける検証を行い, その要因分析とゼロバランスの可能性について 論じる. なお, 本論文は日本建築学会大会学術講演において発表し た内容 ${ }^{5}$ ７）と日本建築学会技術報告集で報告した内容 ${ }^{8}$ に新たな実 証実験データ, 分析結果および考察を加えて作成したものである.

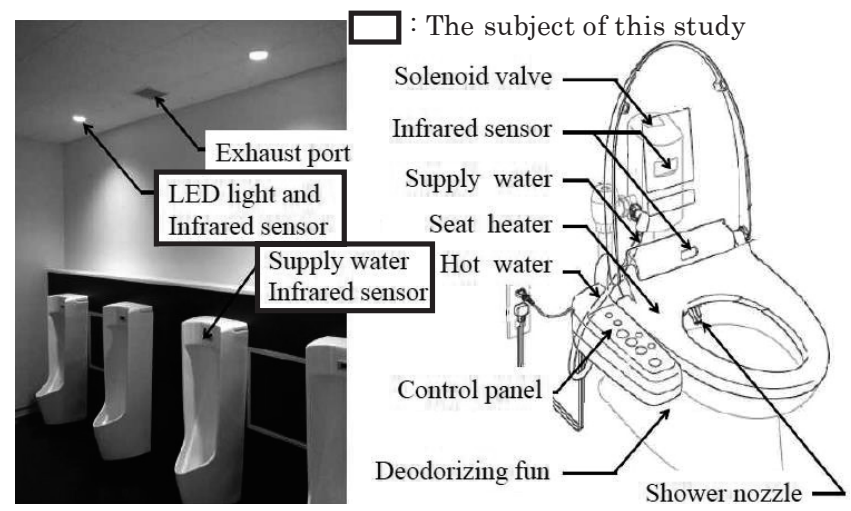

Fig. 1 Breakdown of energy consumption in public toilet ${ }^{6)}$

\section{2. システム概要}

\section{1 ZET 照明システム}

本システムは, トイレ空間内における照明機器類の電力に対して, 給水圧を活用して小型水力発電によりエネルギー回収を行い, その 電力を効率よく充放電する回路, 蓄電池および LED 照明を用いて エネルギー収支のゼロバランスを目指したものである。この ZET 照明システムは, 主に発電部, 消費部, 蓄電部および制御部の 4 つ で構成される(Fig.2)，発電部は, 小便器や大便器ごとに発電ユニット を給水管側に設置しており, 便器使用時と定期清掃時の流水により発電 を行う. 発電された電力は, 制御基板内(以下:ZET 基板)に用意された 高効率回路にて全波整流を掛け DC-DC コンバータにより降圧し, ZET 基板内の Li-Ion 蓄電池に蓄える. 蓄えられた電力は, 人感センサにより 制御された LED 照明の電源, ZET 基板での制御電力およびセンサ待機
電力として活用する. 蓄電不足時には電池による外部供給の運用が可 能であり, 常用は AC 電源による急速充電機能も設けている.

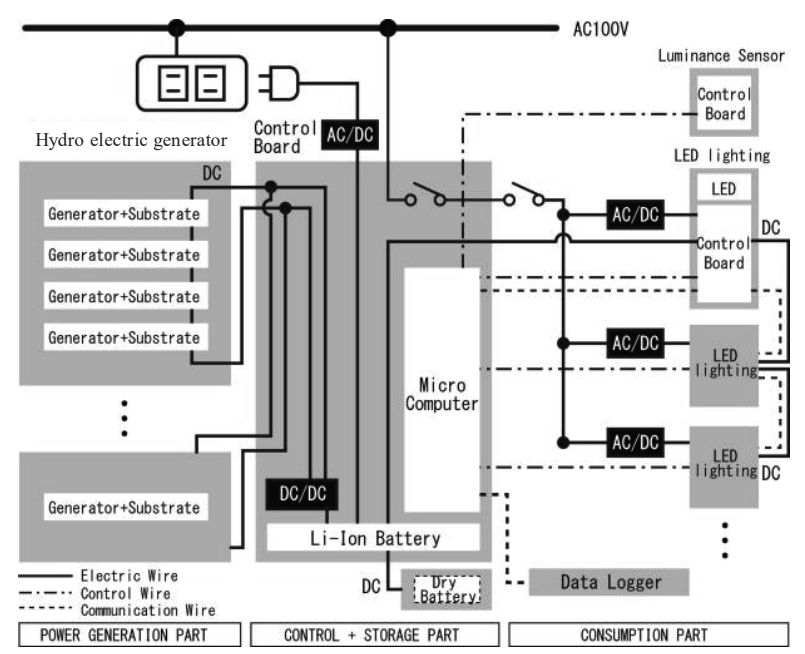

Fig.2 Outline of ZET lighting system ${ }^{6), 8)}$

\section{2 圧力損失と発電特性}

小便器や大便器などの衛生機器は, 流水により便鉢を清掃するが, その際, 機器に応じた所定の給水水圧を要する. 特に本システムで は, 給水側に発電機が設けられるため, 発電機の圧力損失も併せて 検討する必要がある. 本システムの発電機は, 従来品に改良を加え, 小便器用と大便器用を用意した。発電能力と圧力損失は, 相反関係 にあり適宜調整を要する。 そこで, 実証実験に先立ち, 小便器と大 便器ユニットについて, 圧力損失特性と疑似負荷電圧時の発電特性 を確認した. その結果を Fig.3, Fig.4 および Table1 に示す. 図中, 縦軸は圧力損失 $[\mathrm{kPa}]$, 電力 $[\mathrm{W}]$ であり, 横軸は流量 $[\mathrm{L} / \mathrm{min}]$ である.
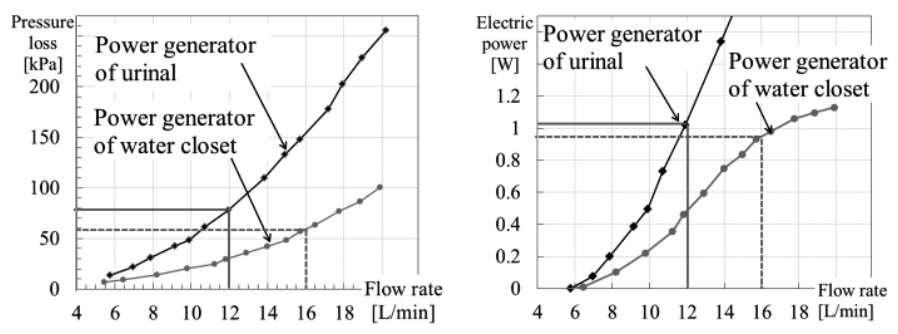

Fig. 3 Pressure loss-Flow rate curve ${ }^{6)}$ Fig.4 Electric power-Flow rate curve ${ }^{6)}$

Table1 Pressure condition of each toilet equipment and power generator

\begin{tabular}{|c|c|c|c|c|}
\hline \multirow[t]{2}{*}{ pressure } & \multirow{2}{*}{$\begin{array}{c}\text { Supply } \\
\text { water } \\
\text { pressure } \\
{[\mathrm{kPa}]}\end{array}$} & \multicolumn{2}{|c|}{ Pressure loss $[\mathrm{kPa}]$} & \multirow{2}{*}{$\begin{array}{c}\text { Water } \\
\text { pressure } \\
\text { capacity } \\
\text { available } \\
{[\mathrm{kPa}]}\end{array}$} \\
\hline & & $\begin{array}{c}\text { Hydro } \\
\text { electric } \\
\text { generator }\end{array}$ & $\begin{array}{l}\text { Sanitary } \\
\text { ware }\end{array}$ & \\
\hline Urinal & \multirow{2}{*}{160} & 79.0 & 50.0 & 31.0 \\
\hline Water closet & & 59.0 & 70.0 & 31.0 \\
\hline
\end{tabular}

小便器用発電機の圧力損失は $12 \mathrm{~L} / \mathrm{min}$ 時において $79 \mathrm{kPa}$ であり, 大便器用は $16 \mathrm{~L} / \mathrm{min}$ 時において $59 \mathrm{kPa}$ であった。今回設置した東北 大学工学研究棟 5 階の当該給水圧力は, $160 \mathrm{kPa}$ 程度が見込まれたた め, 発電機による圧力損失が, この值を下回り, かつ残余圧力と適 正流量で排泄物を処理する必要がある. 小便器全体の圧力損失は $50 \mathrm{kPa}$, 大便器全体の圧力損失は $70 \mathrm{kPa}$ であるから, 発電機の圧力損 
失と機器の圧力損失を給水圧力 $160 \mathrm{kPa}$ から差引き, 小便器大便器共 に残余圧力は $31 \mathrm{kPa}$ となる。この結果を踏まえ, 各実機において, 同時使用下で円滑に流れることを確認した。

一方, 発電特性は, Fig.4 に示す電力 [W]-流量特性[L/min]関係から, 小便器用で $12 \mathrm{~L} / \mathrm{min}$ 時に $1.030 \mathrm{~W}$, 大便器用で $16 \mathrm{~L} / \mathrm{min}$ 時に $0.949 \mathrm{~W}$ の発電能力が得られた。 また, 発電に最適な取出し電圧を把握する ため, $7 \mathrm{~V}, 11 \mathrm{~V}, 17 \mathrm{~V}$ の電圧による発電特性も確認した．流量は, 機器類の都合上, 大学に設置したものよりも大きいが, 傾向は把握 できるため, その流量で確認した. その結果を Fig.5 に示す. 結果 から, 小便器大便器共に同一電圧の運用を想定すると $11 \mathrm{~V}$ 時の発電 が総じて大きいため, 本実証では発電機電圧を $11 \mathrm{~V}$ に設定した。

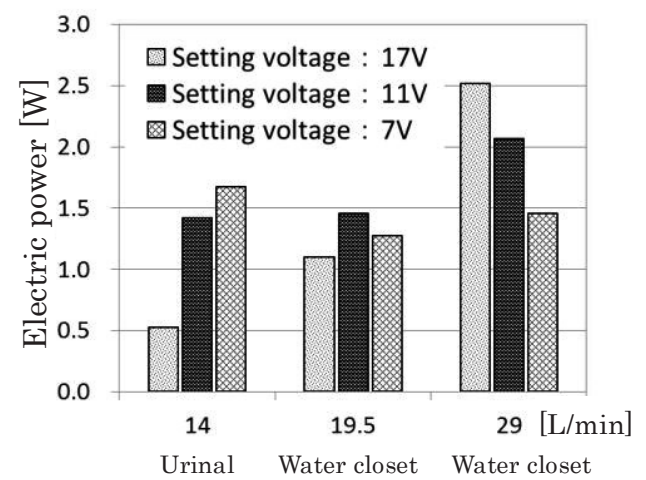

Fig. 5 Power generation capacity by generated voltage and flow rate

\section{3 充放電回路および蓄電池}

充放電回路は, Fig.6 に示す様に水力発電機, 全波整流基板, DC-DC コンバータ, 電流制限器, 放電用負荷抵抗器および LED 駆動回路で 構成される. 各デバイスにおける損失は, 充電回路の全波整流基板 5\%，DC-DC コンバータ 10\%および電流制限器 10\%であり，放電回 路では抵抗損失 $1 \%$, LED 駆動回路損失が $20 \%$ あるる.これらに加 えて, 蓄電池の充電時内部抵抗 $5 \%$ をカウントすると, 充放電回路 効率は $57.9 \%$ となる.このような充放電回路を本実験用に自作した ${ }^{6}$.

電池は自己放電が少なく, 電力密度の高い市販の Li-ion 電池を使 用した.サイズは 18650 (直径 $18 \mathrm{~mm}$, 長さ $65.0 \mathrm{~mm}$ )で容量 3,400mAh, 標準電圧 $3.7 \mathrm{~V}$ であり, 充電, 過放電および過電流保護機能付きであ る. Li-ion 電池の一般的な電圧許容範囲は $3.0 \sim 4.2 \mathrm{~V}$ であるが，充 放電回路の複雑さへの回避と充放電回数を増やすことに注力したた め，今回使用する範囲は 3.4〜 $4.1 \mathrm{~V}$ とした。 それにより，シンプル な制御回路が得られ，使用可能容量も全体容量に対して設計として 6 割を使用可能と想定し, 約 2,040mAh を見込んでいる.

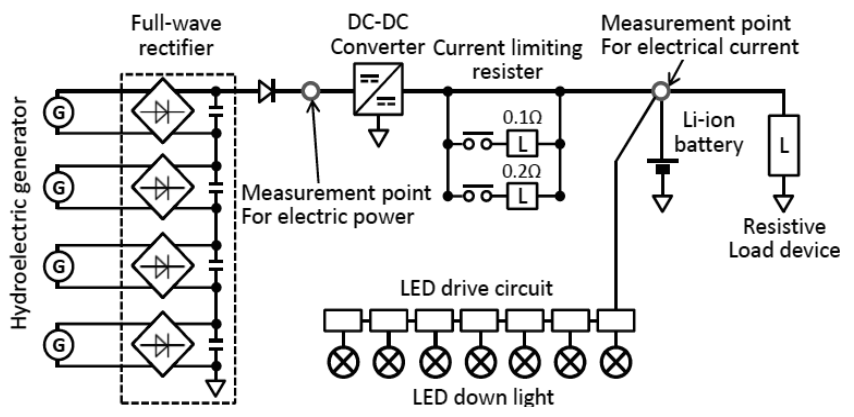

Fig.6 Outline of charge discharge circuit for ZET systems

\section{4 LED 照明}

本研究では，最小の投入エネルギーで高い明るさ感を得るために プルキンエ効果による LED を実験用に開発した ${ }^{6)}$. Photo1 に外観を 示す.この LED 照明は, 中央に赤外線人感センサ, その外周部にプ ルキンエ効果による暗所視用 LED を 6 素子配置, さらにその外周に は $\mathrm{AC}$ 電源用の LED を 30 素子配置することで暗所視と明所視を使 い分ける構成とした。暗所視モードの出力は $0.15 \mathrm{~W}$ である. Fig.7 に全波長領域における絶対視感度のピークに対する比を示す. 開発 した LED 照明(紫色 $7000 \mathrm{~K})$ と従来 LED とを比較すると, 暗所視の ピークである $507 \mathrm{~nm}$ では, その差が顕著である。また, 光源を床面 から $2.7 \mathrm{~m}$ の高さに配置し, 従来品と開発品とを床面に配置した暗 所視照度計で計測比較した結果, 従来品が $7.21 \mathrm{x}$ に対して開発品は $8.91 \mathrm{x}$ と $24 \%$ 性能が向上した。 LED 素子性能の向上とリフレクタな どの調整により，最適な実験用 LED 照明を自作した ${ }^{6)}$.

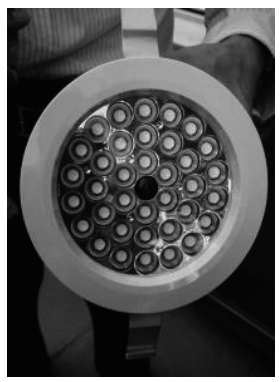

Photo1 LED down light ${ }^{6)}$

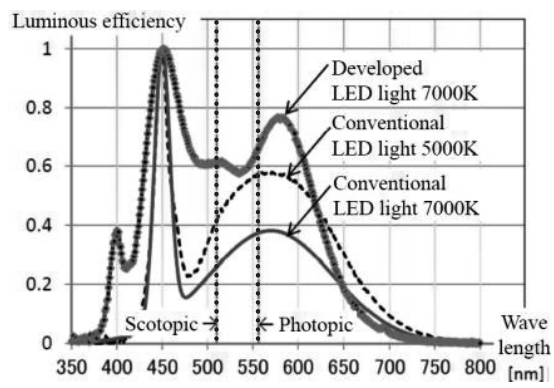

Fig.7 Spectrum of LED lighting developed ${ }^{6)}$

\section{3. 実証サイト}

実証サイトは, 東北大学工学研究科人間・環境系研究棟 5 階の男 女トイレを対象とした(Fig.8). 対象のトイレは，5階の職員や学生 が日常的に利用し，一般的な文教施設における実測データを得られ る環境にある。同トイレは，5階の利用人員を男性 64 人，女性 21 人として適正器具数算定表に基づき器具が設置されている. Fig.9 に 配置図を示寸。男性用卜イレは, 大便器 2 台, 小便器 4 台, 手洗器 2 台, LED 照明 7 灯で構成され, 各便器のみ水力発電機を設置し, 手洗器は将来的に発電機の増設が可能な仕様とした. 男性用トイレ は, 無空のため, 昼夜問わず LED 照明の点灯を要する環境にある. 一方, 女性用卜イレは, 大便器 3 台, 手洗器 2 台, LED 照明 8 灯 が配置され, 男性用トイレ同様に便器にのみ発電機を設置している. ただし，女性用トイレには，西側に全面採光可能なフロストガラス 調の空を有し, 昼光利用が可能であるため, 照度センサを 3 か所に 設置して照明点灯を制御した。また，夜間は，西側に配置された研 究室の照明により間接的に女性用トイレ内が照らされる環境にある.

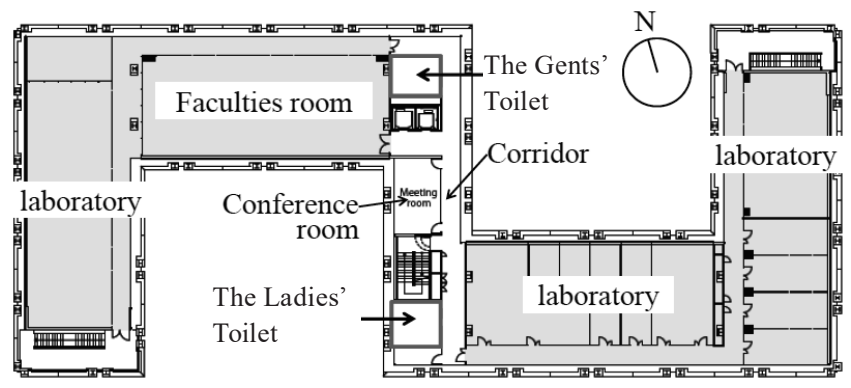

Fig.8 Floor plan of demonstration experiment site ${ }^{7), 8)}$ 


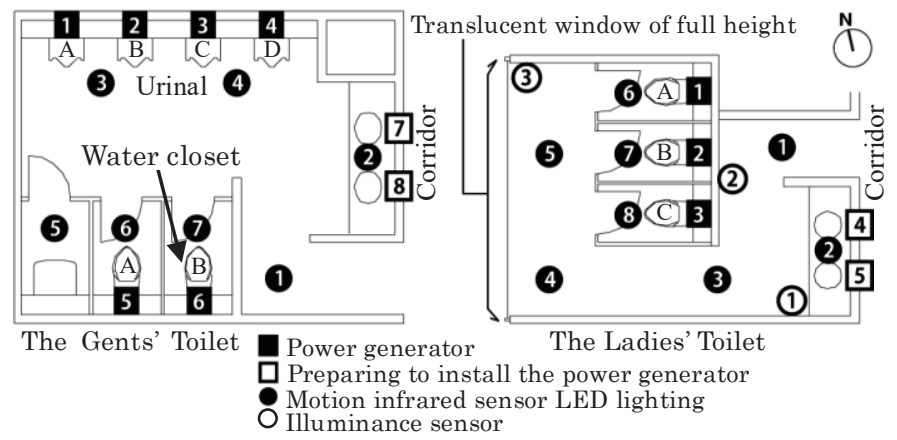

Fig.9 Layout of toilet equipment, power generator and LED lighting ${ }^{7), 8)}$

\section{4. 実験条件}

\section{1 実験方法}

実証実験は，5階利用者の年間スケジュールによって滞在人員の 増減を考慮の上, 閑散期, 通常期, 繁忙期の 3 期に分けて土日を挟 んだ 10 日間で実施した. 実証実験中, 蓄電池の不具合から 2016 年 3 月に実施した閑散期のみ, 1 週間の測定となっている. 実施日程 を Table 2 に示寸，実証実験の実施にあたっては，トイレ入口上部 に実証実験実施中の張り紙をして利用者に周知した.

Table2 Duration of the experiment

\begin{tabular}{c|lc}
\hline Period & \multicolumn{2}{|c}{ The date of implementation } \\
\hline Normal & 28th Nov.2015 - & 7th Dec.2015 \\
\hline Busy & 23rd Jan.2016 - & 1st Feb.2016 \\
\hline Off & 17th Mar.2016 - 23rd Mar.2016 \\
\hline
\end{tabular}

\section{2 計測項目および計測方法}

トイレ内照明エネルギーの収支に関わる影響要因は, 昼光率，発 電量, 充放電回路効率, LED 回路効率, センサ類消費電力, 基板制 御電力, 利用者の振舞い, 機器配置計画などが考えられるが, ここ では, 発電部と消費部における電流電圧および点灯箇所別点灯回数 ついて計測した。計測項目は, 電池電圧 $[\mathrm{mV}]$, 電池電流 $[\mathrm{mA}]$, 電 池残容量 $[\mathrm{mAh}]$, 電池満容量 $[\mathrm{mAh}]$, 各発電機の発電時電圧 $[\mathrm{V}]$, 環 境温度 $\left[{ }^{\circ} \mathrm{C}\right]$, 照度, 各 LED 照明の点灯の有無を 1 秒ごとにカウント した。また，実験開始にあたっては，充電池が満充電や未充電であ ると正確に充放電量を確認できない恐れが想定されるため, 電池残 容量が $50 \%$ の状態から計測を開始した. 女性用トイレの照度センサ は, 床面から $1100 \mathrm{~mm}$ 高さにて(1)〜(3)(Fig.9)のどれか一つでも照 度が $10 \mathrm{~lx}$ 以下となった時点で人感センサが検知する制御とした。

\section{3 機器の特性とモードの決定}

実証実験に採用した小便器には，主に従来モード，節水モード， 超節水モードの 3 種類がある. Table3 に各モードの特徴を示す．小 便器の洗浄は, 予備洗浄と本洗浄で構成される. 予備洗浄は, 尿の 飛散や付着を抑制するため, 使用前に $0.5 \mathrm{~L}$ の洗浄が行われる。一方, 本洗浄は, 即時洗浄と追加洗浄(保護洗浄)で構成され, 即時洗浄は, 使用者が立ち去った直後に行い便鉢を洗浄してトラップ内の封水を 入れ替える役割を果たす。さらに，追加洗浄は，使用者が立ち去っ た後, 次の使用者が予測した時間通りに来なかった場合に追加で行 う洗浄であり，所定の時間間隔で使用状況に応じて適宜追加洗浄が 行われる(Table3). 追加洗浄時には, 実際に人が小便器を使用してい る訳ではないので, LED 照明の消費は無く単に発電のみがカウント
される。本実証実験では，一般的に広く利用されている節水モード を選択した(Table3 網掛け部).

大便器の洗浄には小洗浄と大洗浄があり, 小洗浄と大洗浄の発電 量には違いが生じる，予備実験では，小洗浄は，大洗浄に対して平 均で 0.78 倍の発電量であった。洗浄と大洗浄は, 用途に応じて使 い分けられるが, 必ずしも正確に使い分けられているとは限らない. 通常，男性用トイレでは，トイレブースを使用する主目的は大便時 に限られることが多く，女性用トイレでは小便利用が多いと想定さ れるが, 本実験では, 単にブースの使用回数としてカウントした.

Table3 Flashing type and flashing mode for urinal

\begin{tabular}{|c|c|c|c|}
\hline \multirow[b]{2}{*}{ Mode } & \multirow{2}{*}{$\begin{array}{c}\text { Pre } \\
\text { flashing }\end{array}$} & \multicolumn{2}{|c|}{ Main flashing } \\
\hline & & $\begin{array}{c}\text { Immediately } \\
\text { flashing }\end{array}$ & $\begin{array}{c}\text { Additional } \\
\text { flashing time }\end{array}$ \\
\hline Normal & $0.5 \mathrm{~L}$ & $4.0 \mathrm{~L}$ & - \\
\hline Water conservation & $0.5 \mathrm{~L}$ & $2.0 \mathrm{~L}-4.0 \mathrm{~L}$ & $0.25 \mathrm{hr}-8 \mathrm{hr}$ \\
\hline \multirow{2}{*}{$\begin{array}{l}\text { Super water } \\
\text { conservation }\end{array}$} & $0.5 \mathrm{~L}$ & \multirow{2}{*}{$0.8 \mathrm{~L}-2.0 \mathrm{~L}$} & \multirow{2}{*}{$0.25 \mathrm{hr}-2 \mathrm{hr}$} \\
\hline & None & & \\
\hline
\end{tabular}

\section{4 発電量および消費量}

発電量は, 上水の使用状況に応じて電流值が変動することに加え, 計測は蓄電池出入口近傍のため, 照明点灯による消費側の電流值も 含まれる. そのため, 日当りの総発電量 $[\mathrm{Wh}]$ は, 計測点の発電時電 圧と電流值だけでは導けない，そこで，既知である LED 照明の消 費電流 $50 \mathrm{~mA}$ を用いて各 LED 照明の合計点灯時間をカウントし, 日当りの電池電圧と電池電流の増減から発電量を導いた。消費側電 力量は, LED 照明, LED 基板, ZET 基板およびセンサ類に使用し ている電力量を合算し, LED 駆動効率や放電回路効率を加味した.

一方, 発電側電力量は, 本来, 全波整流回路効率, 降圧用 DC-DC コンバータ効率, 電流制御器効率および充電池効率 (Table4)を見込 む必要があるが, ここでは, 蓄電池近傍の計測点(Fig.6)データから 蓄電池部において消費量と発電量との比較を行った，比較用の消費 量と発電量は, 式(1), 式(2)にて算定した. 式(1)の右辺第 1 項は LED 照明の日当たりの消費電力量を示し, 第 2 項は機器類の待機電力で ある. また,ここでは, 放電時蓄電池内抵抗は小さいため無視した. 式(2)のカッコ内は, 日当りの電池容量の増減であり, これに式(1) の結果を加え, 充電時蓄電池内部抵抗の蓄電池効率と充放電電圧率 を乗じて発電量を導く、エネルギー収支は, これらの比較で判別し た. 式(3)は, 発電機部での各種効率を考慮した際の総発電量である.

$\sum P_{C B}=\frac{I_{L} \cdot\left(\sum_{k=1}^{n} a_{k}\right) \cdot t}{\eta_{d} \cdot \eta_{e}} \cdot V_{D}+\int_{h=0 \sim 24}\left(I_{b}+I_{l}+I_{s}+I_{g}\right) \cdot V_{D}$

$\sum P_{G B}=\left\{\sum P_{C B}+\left(I_{\text {end }} \cdot V_{\text {end }}-I_{\text {start }} \cdot V_{\text {start }}\right)\right\} \cdot \eta_{b} \cdot \frac{V_{C}}{V_{D}}$

$\sum P_{G}=\sum P_{G B} /\left(\eta_{r} \cdot \eta_{c} \cdot \eta_{l} \cdot \eta_{b}\right)$

ここに

$\sum P_{C B}$ : 比較用消費量 $[\mathrm{Wh}] \quad \sum P_{G B}$ : 比較用発電量 $[\mathrm{Wh}] \quad \sum P_{G}$ : 総発電量 $[\mathrm{Wh}]$

$I_{L} \quad$ :LED の定格電流 $[\mathrm{mA}]$ $h \quad$ :時間[h]

$I_{b} \quad: Z E T$ 制御基板電流量 $[\mathrm{HAh}]$

$I_{l}: \mathrm{LED}$ 制御基板電流量 $[\mu \mathrm{Ah}]$

$I_{s}$ : センサ制御基板電流量 $[\mu \mathrm{Ah}] \quad I_{g}$ :発電制御基板電流量 $[\mu \mathrm{Ah}]$

$I_{\text {sart }}$ :開始時電池残容量 $[\mathrm{mAh}] \quad I_{\text {end }}$ : 終了時電池残容量 $[\mathrm{mAh}]$ 
$V_{\text {start }}$ :開始時電圧 $[\mathrm{mV}]$

$a_{k}$ :各照明の日当りの点灯回数

$V_{\text {end }} \quad$ : 終了時電圧 $[\mathrm{mV}]$

$\eta_{d}$ : 放電回路抵抗負荷効率

$\eta_{b}$ : 蓄電効率

$\eta_{r}$ : 全波整流基板効率

$V_{D}$ : 放電電圧平均値 $[\mathrm{mV}]$ $t: 1$ 回当りの点灯時間[sec]

$\eta_{e}:$ LED 照明駆動効率

$\eta_{c} \quad$ :DC-DC コンバータ効率

$\eta_{l}$ : 電流制限器効率

$V_{C} \quad$ :充電電圧平均値 $[\mathrm{mV}]$

Table4 Efficiency of each component [\%]

\begin{tabular}{rc|c|rc|c}
\hline Full wave rectification & $\eta_{r}$ & 95 & DC-DC converter & $\eta_{c}$ & 90 \\
\hline Current limiters & $\eta_{l}$ & 90 & LED drive circuit & $\eta_{e}$ & 80 \\
\hline Discharge circuit & $\eta_{d}$ & 99 & Battery & $\eta_{b}$ & 95 \\
\hline
\end{tabular}

各種機器類の待機電力を Table5 に示す. 放電時電池電圧の平均 值から ZET 基板や LED 基板のセンサなどの待機消費電力量は男性 用トイレで 0.080 [Wh/day], 女性用トイレで 0.084 [Wh/day]となる.

Table5 Standby power consumption of ZET system circuit

\begin{tabular}{r|c|c}
\hline & \multicolumn{2}{|c}{ Energy consumption } \\
\cline { 2 - 3 } & The Gents'Toilet & The Ladies' Toilet \\
\hline ZET circuit board $I_{b}$ & $850 \mu \mathrm{Ah}$ & $850 \mu \mathrm{Ah}$ \\
\hline LED circuit board $I_{l}$ & $5 \mu \mathrm{Ah} \times 7=35 \mu \mathrm{Ah}$ & $5 \mu \mathrm{Ah} \times 8=40 \mu \mathrm{Ah}$ \\
\hline Illuminance sensor $I_{s}$ & - & $4 \mu \mathrm{Ah} \times 3=12 \mu \mathrm{Ah}$ \\
\hline Electric power board $I_{g}$ & $0 \mu \mathrm{Ah}$ & $0 \mu \mathrm{Ah}$ \\
\hline Discharge voltage (av.) $V_{D}$ & $3.756 \mathrm{~V}$ & $3.860 \mathrm{~V}$ \\
\hline Total consumption per day & $0.080 \mathrm{Wh} /$ day & $0.084 \mathrm{Wh} /$ day \\
\hline
\end{tabular}

\section{5. 実験結果および考察}

5.1 男性用トイレ（無空）

日当りのエネルギー収支と各期間で平均化したエネルギー収支を Fig.10に示し, 日当りの総利用者数, 各機器利用者数およびエネル ギー収支を Fig. 11 に示寸. エネルギー収支を示すエネルギーバラン ス率は, 発電量を消費量で除して無次元化した值である. また, Fig. 10, Fig.11では, 12 月 7 日(月)のみセンサに異常を確認したため, このデータを除外した. さらに, 洗面水洗のみの利用, 清掃時の SK 利用は，全体に占める割合が少なかったため，これらも除外した。

実験結果から期間別のエネルギー収支は, 総じて発電量よりも消 費量の方が大きく, エネルギー収支はゼロバランスを保てなかった。 一方, Fig.10 が示すように通常期と閑散期の休日(土日)では, 発 電量が消費量を上回り，ゼロバランスが達成できた．全般的には， 消費量が $1 \mathrm{Wh}$ 以下の時にエネルギーバランス率が 1.0 以上となる傾 向があり, 利用頻度の高い繁忙期では, 全曜日で $1 \mathrm{Wh}$ を超えたため, ゼロバランスできていない，また，利用者が増加するほど消費量と 発電量の乘離が生じる結果となった. したがって, 本システムでは, 消費量が $1 \mathrm{Wh}$ くらいを閾值としてゼロバランスの可否が決定する。

Fig.11 中の数值は, 全利用者数であり, 斜字数值はトイレブース の利用者数を示す. 小便器の利用者数は, 全体からトイレブース利 用者数を差引し算定する. 実験結果から, 各期間共に平日と休日 (土 日)の利用者数による差が大きい. 平日の利用者数は繁忙期 $>$ 通常期 $>$ 閑散期だが, 休日は繁忙期>通常期 の休日は全体を通じて最も利用者数の多い日であった。 また，本シ ステムでは，全利用者数が 61 人以下でトイレブース利用者数が 20 人未満であれば概ねゼロバランス寸るが，この利用者数を超えると

エネルギーバランス率は 1.0 を下回り始める.これは, 利用者の振 舞い方, 機器発電能力および追加洗浄等に関係があると推察する.

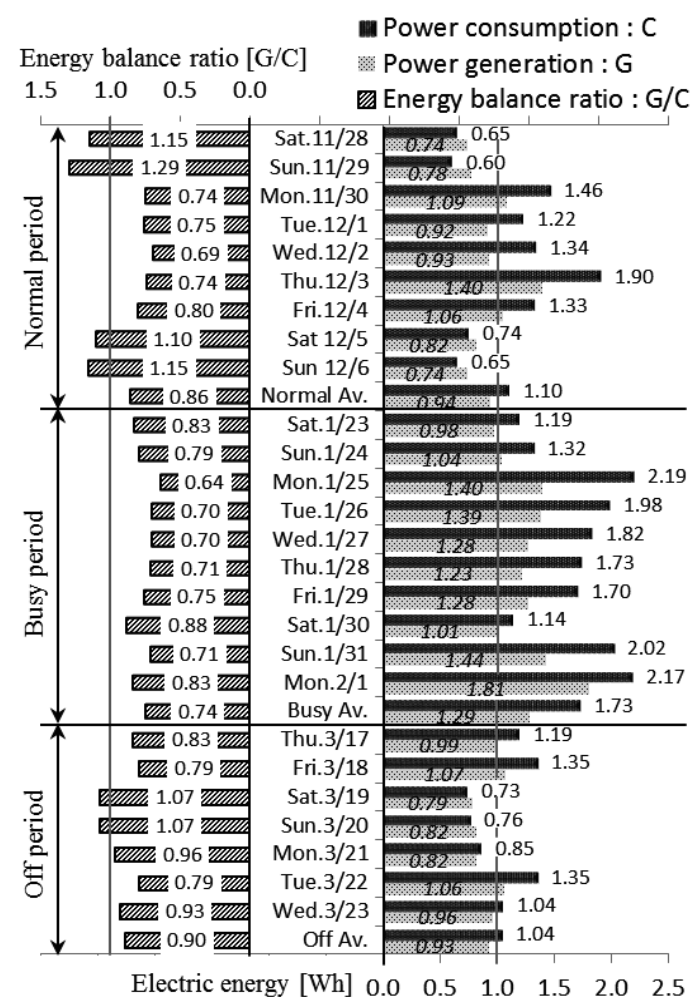

Fig.10 Energy balance for each day in The Gents' Toilet

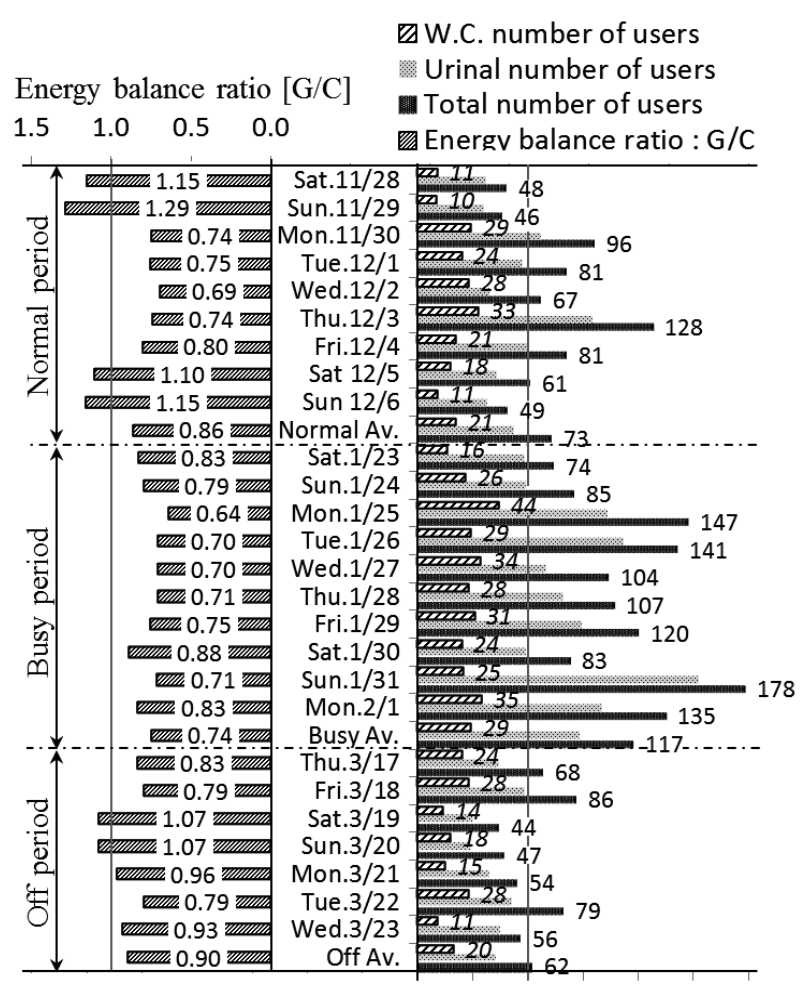

Number of users [persons/day] $030 \quad 60 \quad 90 \quad 120150180$

Fig.11 Total number of users for each day in The Gents' Toilet

次に消費の仕方を把握する上で各便器の平均利用者数を確認する. Table6 には, 各小便器と各トイレブースにおける日当りの平均利用 
者数を期間別にまとめ示す. 期間別平均利用者数は, 通常期 72.9 人に対して繁忙期で 1.6 倍, 閑散期で 0.8 倍である. 小便器利用者 数は，全体の 66.7 75.1\%を占め，その割合は繁忙期が高く閑散期 では低い。また，トイレブースの利用者数は，通常期と閑散期は概 初同じだが，繁忙期は通常期と比べ $42 \%$ 多い. 次に消費電力への影 響を考慮し, 便器やブースの位置ごとの利用頻度を確認する. 実験 結果では, 出入口に一番近い小便器 $\mathrm{D}$ の利用頻度が最も高く, 小便 器利用者数は全体の $65 \sim 69 \%$ を占めた. 続いて, 小便器 $\mathrm{B}$ が高く, 一番奥の小便器 $\mathrm{A}$, 小便器 $\mathrm{C}$ の順となった。 この小便器 $\mathrm{C}$ と最も利 用頻度の高い小便器 $\mathrm{D}$ との差は 7.0〜8.4 倍であった. したがって, 男性用トイレでは, 出入口に一番近い小便器は利用頻度が最も高く, その隣の小便器は最も低く利用を避ける傾向にある。一方, トイレ ブースでは, 出入口に近いブース A に対するブース B の利用回数は $1.2 \sim 1.8$ 倍で小便器ほどの差はない.この要因は, 設置数が少なく, 片方が利用されると選択の余地が無いためである. トイレブースも 小便器同様に出入口に近いブースが選択されることが読み取れる.

Table6 Average usage per day for each toilet equipment [times/day]

\begin{tabular}{c|r|c|c|c|c|c|c|c|c}
\hline \multirow{2}{*}{} & \multirow{2}{*}{ Total } & \multicolumn{5}{|c|}{ Urinal } & \multicolumn{3}{c}{ Water closet } \\
\cline { 3 - 10 } & & $\mathrm{A}$ & $\mathrm{B}$ & $\mathrm{C}$ & $\mathrm{D}$ & Total & $\mathrm{A}$ & $\mathrm{B}$ & Total \\
\hline Normal & 72.9 & 5.9 & 7.4 & 4.9 & 34.2 & 52.4 & 7.2 & 13.3 & 20.5 \\
\hline Busy & 117.4 & 9.3 & 10.4 & 7.3 & 61.2 & 88.2 & 13.2 & 16.0 & 29.2 \\
\hline Off & 59.2 & 3.9 & 5.0 & 3.6 & 27.0 & 39.5 & 7.7 & 12.0 & 19.7 \\
\hline
\end{tabular}

Fig.12 と Fig.13 には, 小便器利用とトイレブース利用の期間別 平均利用者数を時間毎に示す. 平均利用者数の推移は, 各期間共に オフィスアワーに集中し, 繁忙期の小便器のみ深夜から明け方にか けて利用者の増加が確認された。 小便器利用では, 通常期と閑散期 で大きな差はない。また，トイレブースでも，一部を除き期間別に よる大きな差は見られず, 利用者数は小便器に比べ総じて少ない.

Fig.14 は, トイレ出入口人感センサ(Fig.9 照明(1))が検知した期間 別平均検知回数を時間毎に示す。これは, トイレ利用を意図しない 廊下の通行者がトイレ出入口の人感センサに検知された回数であり, トイレ利用目的の検知はカウントしていない. Fig.14 中， 12:00 18:00 では，通常期で 10 [回/h]，繁忙期 15 20 [回/h]，閑散期 5 [回

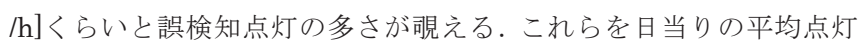
回数で表すと通常期で 122 [回/h] に対し, 繁忙期はその 2 倍, 閑散 期は 0.5 倍であった。また, 繁忙期は, 深夜や明け方の誤検知点灯 もあり,人員の滞在時間の長さや帯在者数に依存した結果と考える.

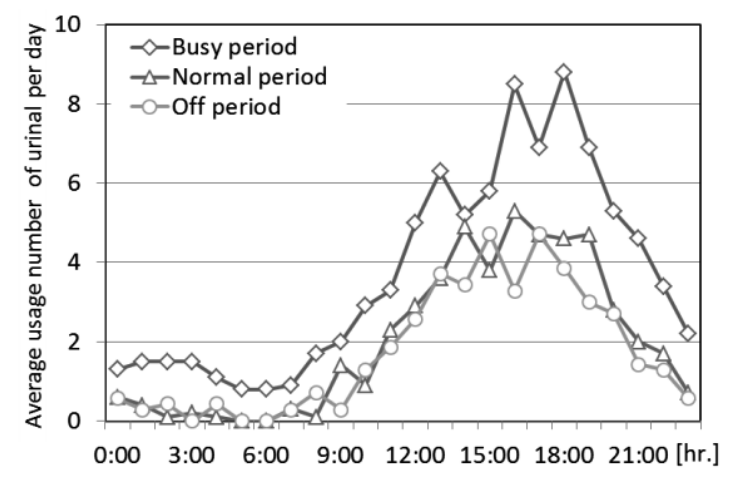

Fig.12 Average usage number of urinal per hour for The Gents' Toilet

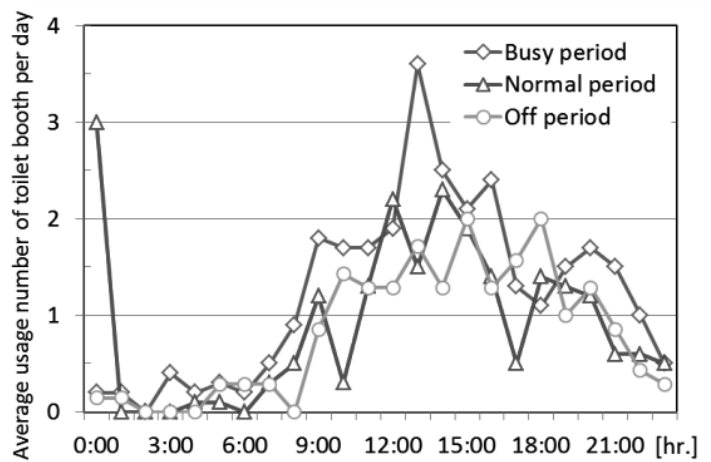

Fig.13 Average usage number of toilet booth per hour for The Gents' Toilet

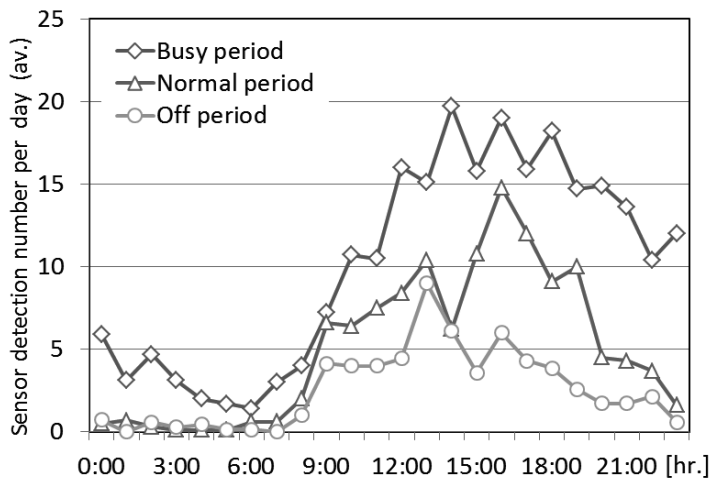

Fig.14 LED sensor detection number of lighting No.(1) per hour

Table7 は, トイレを 1 回使用する際に点灯する LED 照明の平均 点灯回数を示す. 平均点灯回数は, 総じて奥に位置する小便器やブ 一スが多くなる。出入口に近い小便器 D と C は， LED 照明の配置 (Fig.9)から理論上の点灯回数は同じだが，ここでは差が生じた。こ れは, 点灯の必要のない照明センサ検知が原因であり，利用者の振 舞い, 配置計画の影響と推察する.トイレブースでも同様であった。

Table7 Number of LED lighting due to using toilet once [times]

\begin{tabular}{c|r|r|r|r|r|r}
\hline \multirow{2}{*}{$\begin{array}{c}\text { Toilet equipment } \\
\text { Period }\end{array}$} & \multicolumn{5}{|c|}{ Urinal } & \multicolumn{2}{c}{ Water closet } \\
\cline { 2 - 7 } & \multicolumn{1}{c|}{ A } & \multicolumn{1}{c|}{ B } & \multicolumn{1}{c|}{ C } & \multicolumn{1}{c|}{ D } & \multicolumn{1}{c}{ A } & \multicolumn{1}{c}{ B } \\
\hline Normal & 10.7 & 9.7 & 9.8 & 8.2 & 13.2 & 8.5 \\
\hline Busy & 11.7 & 10.9 & 9.8 & 9.0 & 13.3 & 9.9 \\
\hline Off & 11.4 & 11.4 & 11.1 & 8.4 & 12.8 & 10.8 \\
\hline
\end{tabular}

Table8には，トイレを 1 回使用する際の期間別平均消費量と平均 発電量を示す。平均消費量は，トイレで排泄行為を済ませるまでに 要した照明点灯回数分の電力および待機電力の積算值を利用者数で 除した值の期間平均である。また, 平均発電量は, 小便器を例にと ると予備洗浄と本洗浄に加え追加洗浄分も含めた発電量の積算值を 利用者数で除した值の期間平均である.

実験結果から，通常期，繁忙期，閑散期に関わらず，消費量は発 電量より大きく, 発電量で消費量を賄えていない。平均消費量は, 全体で通常期＜繁忙期＜閑散期となるが，小便器利用では，繁忙期 <通常期 <閑散期となり，トイレブース利用では，通常期 $<$ 閑散期 く繁忙期となった。繁忙期の小便器利用では，例えば同時利用者に より消費量が少なく，繁忙期のトイレブース利用ではブース内滞在 時間が長い可能性がある。小便器利用とトイレブース利用における 平均消費量の差は $1.1 \sim 1.4$ 倍と後者の方が多く, これは, 点灯回数 
と滞在時間に依存する。平均発電量は, 小便器利用において繁忙期 <通常期<閑散期であり, 繁忙期における 1 回当りの発電量が少な くなる原因は, 追加洗浄が減少したためである. 追加洗浄は, 利用 者数が増えるほど洗浄回数が減少し, 1 回当りの発電量は少なくな る. また, トイレブース利用では, 繁忙期 $<$ 通常期<閑散期となり, 通常期と閑散期は概水同じで繁忙期よりも発電量は多い。これは, 1 度の利用で 2 回以上洗浄を行った結果と推察する. さらに, 小便 器とトイレブースの比較では, トイレブースの発電量が小便器の 1.1〜 1.4 倍となり, 追加洗浄を除くと $1.5 \sim 1.8$ 倍まで拡大する. 本システムでは, 利用者数が 61 人以下の場合に消費量は約 $1 \mathrm{Wh}$ となり, 1 回当りの利用によるエネルギー収支が消費量 > 発電量で あっても追加洗浄によりゼロバランスの可能性は高まるが, 利用者 数が 61 人を超えると追加洗浄回数が減少する. そのため, 消費量 と発電量の間で乘離が生じ, その差は拡大していく.つまり, 消費 量と発電量の差分は, 追加洗浄により消費量 $1 \mathrm{Wh}$ までは賄えるが, それ以降はセロバランスが保てない。したがって, ZET システムで は, 利用者数, 誤検知回数, 機器設置計画, 追加洗浄および利用者 の振舞いがエネルギー収支に影響することが明らかとなった。

Table8 Consumption and generation per using toilet once [mWh/time]

\begin{tabular}{c|c|c|c|c|c|c|c|c}
\hline \multirow{2}{*}{ Period } & Total & Urinal & W.C. & $\begin{array}{c}\text { Total } \\
\text { Incl.added } \\
\text { flashing }\end{array}$ & $\begin{array}{c}\text { Total } \\
\text { Exc.added } \\
\text { flashing }\end{array}$ & $\begin{array}{c}\text { Incl.added } \\
\text { flashing }\end{array}$ & $\begin{array}{c}\text { Exc.added } \\
\text { flashing }\end{array}$ & \multirow{2}{*}{ W.C. } \\
\hline Normal & 14.83 & 14.24 & 17.36 & 13.52 & 9.43 & 12.78 & 8.95 & 16.34 \\
\hline Busy & 14.95 & 13.82 & 19.27 & 11.30 & 9.33 & 10.44 & 8.62 & 14.53 \\
\hline Off & 16.80 & 16.78 & 17.89 & 15.46 & 11.00 & 15.44 & 10.97 & 16.49 \\
\hline
\end{tabular}

\section{2 女性用トイレ（有悹）}

各期間におけるエネルギー収支の平均值と一日当りのエネルギー 収支を Fig.15に示す. エネルギー収支を表すエネルギーバランス率 は，発電量を消費量で除して無次元化した值である。また，女性用 トイレは, 昼光利用が可能だがトイレブース内は日中でも薄暗く感 じることと利用者の振舞いを確認する目的で, 閑散期のブース内に 限り日中でも LED 照明が人感センサで検知点灯するよう改良した。 実験結果から通常期之繁忙期の各期間別エネルギー収支はゼロバ ランスできたが, 閑散期は消費量が大幅に増加し, エネルギー収支 のゼロバランスは未達となった。 消費量と発電量ともに, 閑散期> 繁忙期 > 通常期となるが, 消費量は通常期 $0.084 \mathrm{Wh}$ と比べ繁忙期 1.9 倍, 閑散期 5.6 倍と閑散期の消費量増加が顕著であった。一方, 発電量は, 通常期と繁忙期において日曜日とその翌日を除き, 発電 量が消費量の $1.5 \sim 4.8$ 倍と大きいが, 通常期の日曜日とその翌日は 利用者が少ないため, 待機電力 $0.084 \mathrm{Wh}$ を発電量で賄えていない.

Fig.16には, 日当りの利用者数を示す. 通常期と繁忙期は, 利用 者数が 40 人以上でゼロバランスする傾向にあり, 当然, 利用者数 が少なければゼロバランスできない。閑散期では, 日当りの平均利 用者数が通常期と概水同等にも拘らず, 消費量は格段に増加した (Fig.15)。これは, 比較実験において日中のブース内照明を人感セ ンサにより検知点灯する運用にしたことが主な原因である.

各トイレブースにおける日当りの平均利用者数を期間別にまとめ Table9 に示す. 通常期と閑散期は, 男性用トイレと概祆同じであり, 繁忙期は通常期の 1.58 倍であった. ブースの利用状況は, 一番手前
のブース $\mathrm{C}$ が圧倒的に多く, 全利用者数の $56 \sim 69 \%$ 占めた. 通 常期と閑散期の利用者数は $\mathrm{A}>\mathrm{B}$ だが，繁忙期は $\mathrm{A}<\mathrm{B}$ となった. 通常期は男性用トイレ同様に利用者が隣り合うことを避ける傾向に あるが，繁忙期では時間的余裕の無さからか，手前側ブースの選択 を助長したと推察する. また, 昼光利用時の利用者率は全体の 37.6 〜 48.2\%を占め, 消費量削減への寄与度が伺える結果となった.

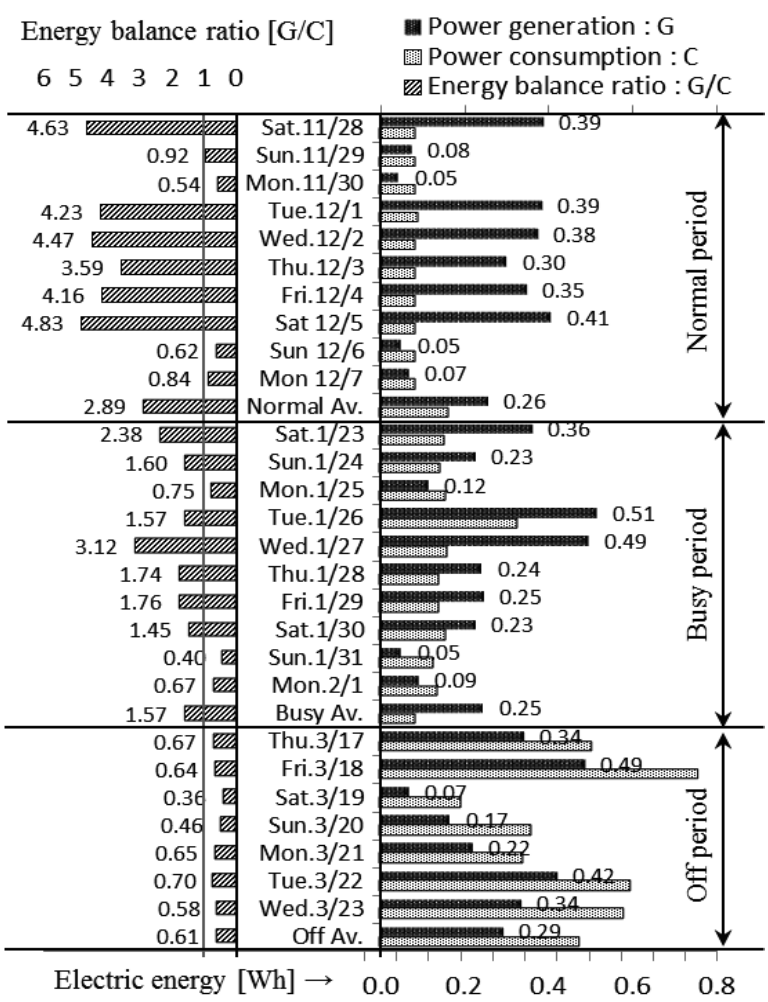

Fig.15 Energy balance situation for each day in The Ladies' Toilet

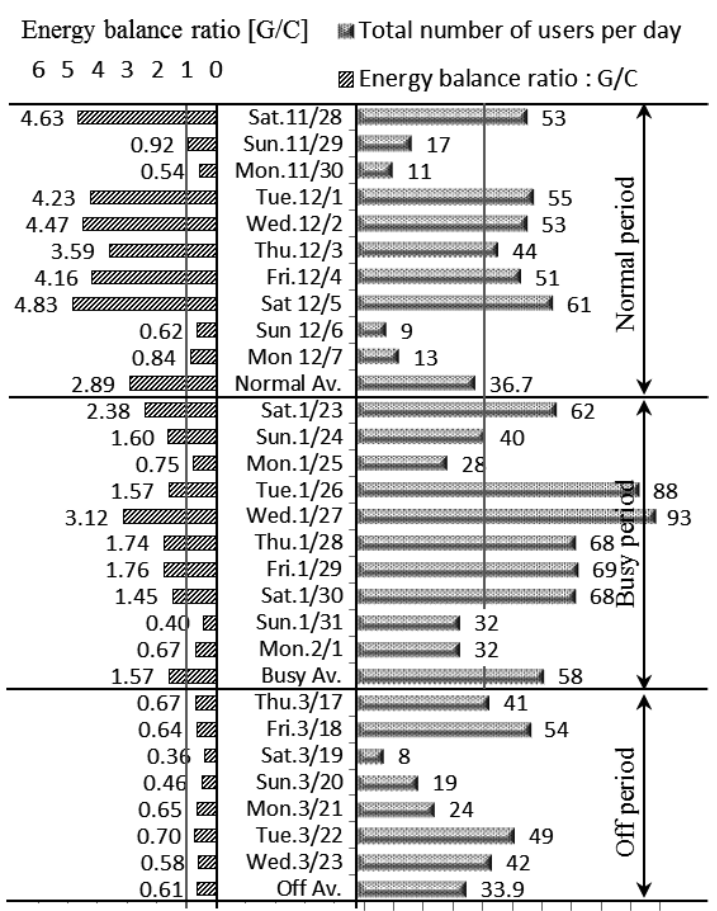

Number of users [persons] $\rightarrow 0.0 \quad 20.0 \quad 40.0 \quad 60.0 \quad 80.0$

Fig.16 Total number of users for each day in The Ladies' Toilet 
Table9 Average number of users for toilet booth in The Ladies' Toilet

\begin{tabular}{c|c|c|c|c|c}
\hline Booth & \multicolumn{5}{|c}{ Toilet booth [times/day] } \\
\cline { 2 - 6 } Situation & Total & $\mathrm{A}$ & $\mathrm{B}$ & $\mathrm{C}$ & Users of 9:00-14:59 \\
\hline Normal & 36.7 & 9.3 & 6.5 & 20.9 & 15.5 \\
\hline Busy & 58.0 & 11.4 & 14.2 & 32.4 & 21.8 \\
\hline Off & 33.8 & 6.3 & 4.1 & 23.4 & 16.3 \\
\hline
\end{tabular}

Fig.17 には, 各トイレブースの期間別平均利用者数を時間毎に示す. 全期間の消費は，オフィスアワーに集中している。通常期と繁忙期 は，オフィスアワーで概同じ傾向にあり，閑散期のみ利用者数が 減少した。また，繁忙期では，深夜から明け方のカウントが多く， 男性用トイレ同様に大学での長時間滞在が要因の一つと考えている.

Fig.18には，トイレ出入口の照明センサ(Fig.9 照明(2)が検知した 期間別平均検知回数を時間毎に示す。これは，男性用トイレ同様に， トイレ利用を意図せず，廊下を通行するなどしてセンサに検知され た回数である。Fig.18中，通常期は検知されておらず，繁忙期と閑 散期は昼光利用時間を除くオフィスアワー，夜間，深夜および明け 方に検知された. Fig.18 中の網掛部 9:00-14:59 は, 昼光利用可能領 域で照度センサが閾值を下回らず人感センサが作動しないが, 照度 センサ(2)は西側空近傍に位置するセンサ(1), (3)よりも暗く影になる 出入口付近に配置したため, 計測值としては安全側の結果となる.

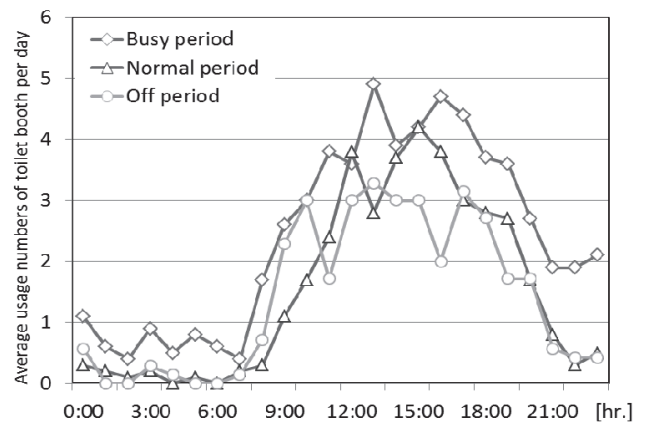

Fig.17 Average number of users per hour for toilet booth

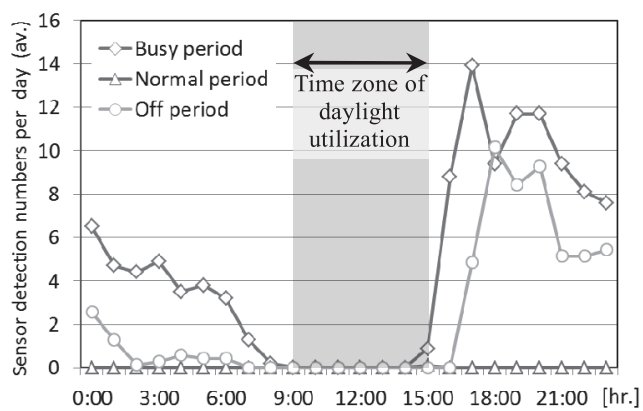

Fig.18 Sensor detection number of users per hour for toilet booth

Table10 は，トイレを 1 回使用する場合の期間当りの平均消費量 と平均発電量を示す. 平均消費量は, トイレでの排泄行為を済ませ るまでに要した LED 照明の点灯回数による消費量および待機電力 の積算值を利用者数で除した值である. また, 平均発電量は小洗浄 と大洗浄により発電された積算電力量を利用者数で除した值である. 実験結果から通常期と繁忙期の消費量は, 発電量よりも小さいため, 発電量で消費量は賄えるが，閑散期では発電量に対して 1.8 倍ほじ 消費量が増加した。閑散期の消費量は, 通常期よりも平均利用者数 が少ないにも拘らず，4.2〜5.0 倍に増加した。この要因は，誤検知
点灯と比較実験により閑散期のみ尽光利用時の人感センサ検知を行 ったためである。誤検知点灯は，繁忙期に比べて閑散期では少なく 要因から除外できるため，主要因はトイレブース内で LED 照明を 連続点灯させたことに絞られる。また，発電量は，通常期や繁忙期 と比べて，閑散期は 1.4 2.1 倍増加した。閑散期は，トイレ利用者 数が通常期と比べ $8 \%$ ，繁忙期で $42 \%$ 少ないが，それでも発電量は 増加した。これは，1回のトイレ利用に対して複数回洗浄を行って いる可能性が高い，何故，複数回洗浄を行うのかの原因は特定でき ていないが，利用者は少なくても発電量が増加する結果となった.

Table10 Power consumption and generation per using toilet once

\begin{tabular}{|c|c|c|c|c|c|c|c|c|}
\hline \multirow{3}{*}{$\begin{array}{r}\text { Booth } \\
\text { Situation }\end{array}$} & \multicolumn{4}{|c|}{ Power Consumption [mWh] } & \multicolumn{4}{|c|}{ Power Generation [mWh] } \\
\hline & \multirow{2}{*}{ Total } & \multicolumn{3}{|c|}{ Toilet booth } & \multirow{2}{*}{ Total } & \multicolumn{3}{|c|}{ Toilet booth } \\
\hline & & A & B & $\mathrm{C}$ & & A & B & $\mathrm{C}$ \\
\hline Normal & 3.81 & 0.97 & 0.68 & 2.17 & 6.16 & 1.57 & 1.08 & 3.50 \\
\hline Busy & 3.17 & 0.62 & 0.78 & 1.77 & 4.18 & 0.85 & 1.04 & 2.29 \\
\hline Off & 15.86 & 2.91 & 1.92 & 10.85 & 8.66 & 1.45 & 1.24 & 5.97 \\
\hline
\end{tabular}

女性用トイレは，男性用トイレに比べ利用者数は少なく，消費量 発電量共に限られるが，昼光利用により消費量は抑制できる。その ため，エネルギー収支ゼロの達成率は高い。しかしながら，女性用 トイレは，旗竿型経路(Fig.9)により，夜間等には本来点灯の必要が ない照明による消費量増加が懸念される。また，トイレブースの利 用頻度は，一番手前のブース $\mathrm{C}$ が高いが，利用前に隣ブースの確認 等選択行動による迷い，利用後の忘れ物や洗浄状況の再確認行動と 思われる点灯も散見された。この結果から，プランニングと機器の 配置計画, センサの検知範囲および検知方法が重要であると考える.

\section{6. 実験結果に基づく改善検討}

\section{1 男性用トイレ}

実験では，エネルギ一収支の影響要因として発電能力や機器消費 電力, 誤検知点灯数および利用者の振舞いが確認された.ここでは, 誤検知の削減や動線計画および昼光利用などのケーススタディーを 行い，エネルギーゼロバランスの可能性を確認する.

ZET 照明のエネルギー消費量は，利用者数，機器の配置，センサ の検知範囲や方法および人々の振舞いに影響される。実験では，小 便器利用に対してトイレブース内の照明も点灯するなど本来必要の ない照明点灯が確認された。そこで，ここでは，排泄行為時の誤検 知による点灯削減に加え，理想的な点灯予測回数と現実的な点灯予 測回数および照明点灯のさせ方について検討した. Fig.19 は便器に 至る動線を示し，Table11 には各便器における理想点灯モデルと現 実点灯モデルおよび点灯回数を示す. 理想点灯モデルは目的の便器 に迷いなく到達し最小限の点灯数となる行動であり，現実点灯モデ ルは理想点灯モデルに排泄行為時だけ当該便器にて連続点灯を追加 したものである.これらの点灯パターンは，実験でも確認されてお り，排泄行為時における誤検知点灯の削減を含んでいる。さらに， 点灯のさせ方では，Fig.20の点灯モデルを想定した．実験での通常 点灯は，同じ出力レベルで 7 秒間点灯し続けるが，エネルギー削減 モデルでは，極端に明るさを損なわず点灯後と消灯前に出力調整を 行い, 通常点灯に比べて $6 / 7$ 秒モデルで $14.3 \%, 5 / 7$ 秒モデルで $28.5 \%$ 削減が可能となる。このモデルで削減した消費量を全消費量から減 じてエネルギーバランス率を算定した. その結果を Table 12 に示す. 


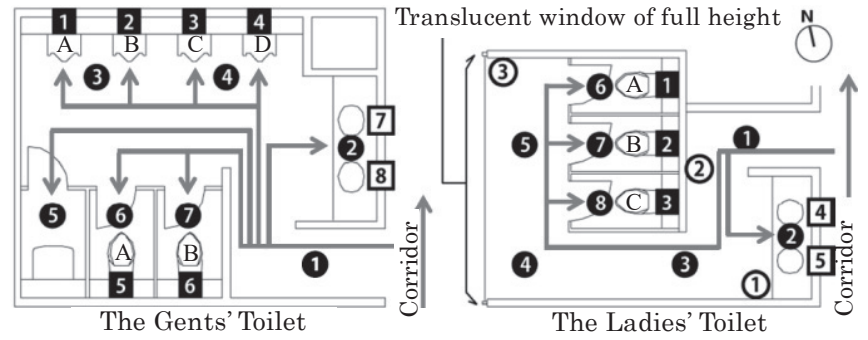

The Gents' Toilet

- Power generator $(\mathrm{PG})$

Illuminance sensor

$\square$ Preparing to install the Power Generator

Fig.19 Usage pattern regarding flow line plan for The Toilets

Table11 Ideal lighting pattern and number of lighting times for The Gents' Toilet

\begin{tabular}{|c|c|c|c|c|c|}
\hline \multicolumn{2}{|c|}{ No. } & \multicolumn{2}{|c|}{ Ideal lighting model } & \multicolumn{2}{|c|}{ Realistic lighting model } \\
\hline \multirow{4}{*}{ 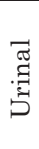 } & A & (1)(2)(4)(3)(4)(2)(1) & 7 & '(1)(2) (4)(3) (3)(3) (4)(2) (1) & 9 \\
\hline & B & '(1)(2)(4)(3) (4)(2)(1) & 7 & '(1)(2) (4)(3)(3)(3) (4)(2) (1) & 9 \\
\hline & $\mathrm{C}$ & (1)(2)(4)(2)(1) & 5 & (1)(2)(4)(4)(4) (2) (1) & 7 \\
\hline & $\mathrm{D}$ & (1)(2)(4)(2)(1) & 5 & (1)(2)(4)(4)(4) (2)(1) & 7 \\
\hline \multirow{2}{*}{$\stackrel{0}{3}$} & A & '(1)(2)(4)(3)(6) (3) (4)(2) (1) & 9 & '(1)(2)(4)(3) (6)....6(3)(4)(2)(1) & 13 \\
\hline & B & '(1)(2)(4)(7) (4)(2)(1) & 7 & (1)(2) (4) (7)...(7) (4)(2)(1) & 11 \\
\hline
\end{tabular}
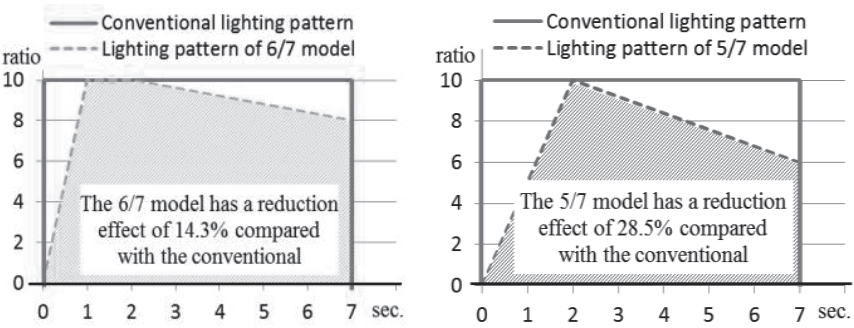

Fig.20 Lighting pattern of reduce energy consumption model

Table12 中，網掛部はゼロバランスした部位である。誤検知@に よる点灯のみ削減したモデルでは，全体のエネルギー消費に対して 2.8〜 6.4\%, 理想モデル(b)゙゙ 9.6 15.7\%, 現実モデル(C) 3.5〜 $8.0 \%$ 削減が可能となった。しかしながら, 誤検知@と現実モデル (C)゙けではゼロバランスはしない。また，理想モデルbでは，通常 期と閑散期でエネルギーバランス率が 1.0 を上回るが，全期間では ない，一方，照明の出力調整をした $6 / 7$ 秒モデル (d)，理想モデル (b) と同様に全期間によるゼロバランスは達成できていないが，5/7 秒モデル@を採用することで全期間ゼロバランスが可能となる結果 を得た。そこで，6/7 秒モデル(d)との組合せによる検討を行う。現 実モデル(C)との組み合わせでは, ゼロバランスは可能となるが全 期間ではなく，理想点灯モデル(b) d との組み合わせにより，全期 間でのゼロバランスが可能となった。本検討結果から，無駄な点灯 削減と点灯のさせ方による削減を組夕合わせることで，昼光利用が 無い場合でもエネルギー収支ゼロが十分に実現できる見通しを得た。

Table12 Energy balance rate regarding each reduction model for The Gents' Toilet

\begin{tabular}{l|c|c|c}
\hline \multirow{2}{*}{$\begin{array}{l}\text { Peduction behavior } \\
\text { and Lighting pattern }\end{array}$} & Normal & Busy & Off \\
\cline { 2 - 4 } & 0.858 & 0.745 & 0.895 \\
\hline Experimental result & 0.905 & 0.795 & 0.921 \\
\hline (a) Sensor detection & 1.019 & 0.918 & 1.026 \\
\hline (b) Ideal lighting & 0.934 & 0.840 & 0.945 \\
\hline (c) Realistic lighting & 1.001 & 0.869 & 1.045 \\
\hline (d)The 6/7 model & 1.201 & 1.043 & 1.254 \\
\hline () The 5/7 model & 1.090 & 0.979 & 1.103 \\
\hline C) + d & 1.189 & 1.071 & 1.197 \\
\hline (b) + (d) & & &
\end{tabular}

次に男性用トイレが昼光利用した場合の余力を検討する。条件は 女性用トイレの実験結果と同じ 9:00-14:59 間で昼光を利用可能と した. Table13の上段には, 昼光利用時における出入口誤検知回数, 小便器利用者数およびブース利用者数を示し，下段には昼光利用時 削減後の日当りの消費量とゼロバランス率を各モデルと組合せモデ ルとして示した。ここに，昼光利用のみ削減した状態を(f)とする. 検討結果から，昼光利用だけでは全期間でゼロバランスはできない が，誤検知（と組み合わせれば，ゼロバランスが可能である.また， 理想(b)と現実(c)の組み合わせでは，大幅な効果向上が見込め，昼光 利用(f) と理想モデル(b)では，1.78～4.31倍の余力が得られる.さら に，無空との比較では $1.65 〜 3.62$ 倍の余力を有する結果を得た。

Table13 Reduction effect of lighting energy by using daylight for The Gents' Toilet

\begin{tabular}{|c|c|c|c|c|c|c|c|}
\hline \multicolumn{2}{|c|}{ Reduced behavior } & \multicolumn{2}{|c|}{ Normal } & \multicolumn{2}{|c|}{ Busy } & \multicolumn{2}{|c|}{ Off } \\
\hline \multicolumn{2}{|c|}{ Lighting detection [Times/day] } & \multicolumn{2}{|c|}{79.2} & \multicolumn{2}{|c|}{45.5} & \multicolumn{2}{|c|}{31.2} \\
\hline \multicolumn{2}{|c|}{ Urinal users [Persons/day] } & \multicolumn{2}{|c|}{24.7} & \multicolumn{2}{|c|}{16.0} & \multicolumn{2}{|c|}{13.1} \\
\hline \multicolumn{2}{|c|}{ W.C. users [Persons/day] } & \multicolumn{2}{|c|}{13.2} & \multicolumn{2}{|c|}{8.8} & \multicolumn{2}{|c|}{7.9} \\
\hline \multicolumn{2}{|c|}{ Result of parametric study } & [Wh] & ratio & [Wh] & ratio & [Wh] & ratio \\
\hline \multirow{4}{*}{$\begin{array}{c}\text { Total energy } \\
\text { consumption } \\
{[\mathrm{Wh}]}\end{array}$} & $(f$ Daylight & 0.49 & 1.94 & 1.32 & 0.97 & 0.67 & 1.40 \\
\hline & (f)+(a)Detection & 0.43 & 2.22 & 1.29 & 1.00 & 0.66 & 1.42 \\
\hline & (f)+(b)Ideal & 0.26 & 4.31 & 0.97 & 1.78 & 0.52 & 1.98 \\
\hline & (f)+(C) Realistic & 0.34 & 3.24 & 1.10 & 1.57 & 0.60 & 1.73 \\
\hline
\end{tabular}

\section{2 女性用トイレ}

女性用トイレでは，男性用トイレ同様に誤検知の削減や動線など のケーススタディーを行い，ゼロバランスの可能性を確認する.

Fig.19に女性用トイレの各便器別動線を示し, Table14には, 各便 器別点灯モデルと点灯回数を示す。ここでは，ゼロバランスしなか った閑散期を対象とし検討を行った。エネルギー削減方法は，LED 照明の点灯回数を削減することでゼロバランスの可能性を確認した Table15 に検討結果を示す。閑散期の女性用トイレでは，誤検知@ や理想モデル(b)，現実モデル(c)よび照明点灯のさせ方などを検討 したが，どれもゼロバランスはできていない。しかしながら，理想 モデル(b)と $5 / 7$ 秒モデル@を組み合せた場合には，ゼロバランスが 実現できた。したがって，本システムでは，トイレブース内点灯を 昼光利用時に行わなくても済む工夫(例えば半透明なドア)が必要で あり,それにより, セロバランスの可能性は大幅に高まると考える.

Table14 Ideal lighting pattern and number of lighting times for The Ladies' Toilet \begin{tabular}{l|l|l|l:l}
\hline & \multicolumn{3}{|c|}{ Ideal lighting pattern } & \multicolumn{2}{c}{ Realistic lighting pattern } \\
\hline $\mathrm{A}$ & (1)(2)(3)(4)(5)(6) (5)(4)(3)(2)(1) & 11 & (1)(2)(3)(4)(5)(6)(6)(6) (5)(4)(3)(2) (1) & 13 \\
\hline $\mathrm{B}$ & (1)(2)(3)(4)(5)(7)(5)(4)(3)(2)(1) & 11 & (1)(2)(3)(4)(5)(7)(7)(7) (5)(4)(3)(2) 1 (1) & 13 \\
\hline $\mathrm{C}$ & (1)(2)(3)(4)(8) (4)(3)(2)(1) & 9 & (1)(2)(3)(4)(8)(8)(8)(4)(3)(2)(1) & 11 \\
\hline
\end{tabular}

Table15 Energy balance rate regarding each reduction model for The Ladies' Toilet

\begin{tabular}{l|c|c|c}
\hline \multirow{2}{*}{$\begin{array}{c}\text { Period } \\
\text { Reduction behavior } \\
\text { and Lighting pattern }\end{array}$} & Normal & Busy & Off \\
\cline { 2 - 4 } & & 1.573 & 0.611 \\
\hline Experimental result & 2.894 & 2.400 & 0.634 \\
\hline (a) Sensor detection & 2.895 & 2.400 & 0.723 \\
\hline (b) Ideal lighting & 2.895 & 2.400 & 0.676 \\
\hline (c) Realistic lighting & 2.895 & 1.835 & 0.713 \\
\hline (d)The 6/7 model & 3.376 & 2.202 & 0.856 \\
\hline ()The 5/7 model & 4.051 & 3.360 & 1.012 \\
\hline (b) +() & 4.053 & 3.360 & 0.946 \\
\hline (c) +(e) & 4.053 & & \\
\hline
\end{tabular}




\section{3 限界利用者数の検討}

ここでは, 本システムの限界利用者数を予測する. 非常時の利用 者数や振舞いは常時と同じではないが, 実験結果から限界利用者数 の定量化を試みた。限界利用者数は，式(4)にて算定した。計算は, 非常時 72 時間対応 $(d=3)$, 避難者一人当り日当りのトイレ使用回 数 $n$ は 6 回, トイレ利用一回当りの発電量と消費量は Table 8,10 から厳しい值を抽出した。また, 非常時の蓄電池容量は, 実験同様 $50 \%(a=0.5)$ とし, 男性用のみ追加洗浄の有無を検討した.さらに, 被災した東北大学工学部では, 本件より 2 倍以上便器の多いトイレ を有する食堂棟に当時約 200 人) (男女比 3:1)が避難しており, 本実 験フィールドにその人員が避難した場合の必要電池容量も検討した.

$N_{L}=\frac{I_{B} \cdot a \cdot V_{B a v}}{\left(P_{C}-P_{G}\right) \cdot n \cdot d} \quad$ 式(4) $\quad d \quad$ :非常時継続日数 [days]

$\begin{array}{clcl}P_{C} & \text { :平均消費電力量 }[\mathrm{mWh} / \mathrm{time}] & P_{G} & \text { :平均発電量 }[\mathrm{mWh} / \mathrm{time}] \\ N_{L} & \text { :限界利用者数 }[\mathrm{persons}] & a & \text { :蓄電池容量係数 } \\ I_{B} & \text { :電池電流量 }[\mathrm{mAh}] & V_{B a v} & \text { :平均電池電圧 }[\mathrm{mV}]\end{array}$

$n$ : 避難者一人当たりー日当りの想定トイレ利用回数 [times/(day· person)]

検討結果から男性用の限界利用者数は, 追加洗浄有りが 57 人で 無しが 37 人, 女性用は 29 人となった. しかし, 非常時蓄電池容量 の閾值を $50 \%$ 超（ $a>0.5)$ とすれば, 限界利用者数はさらに向上寸る.

一方, 当時の避難人員を想定した追加洗浄無しの男性用トイレで は, 同蓄電池 2 本を並列とし, 蓄電池残量の閾值を $100 \%$ とすれば, 限界人員 150 人を満たせる. また, 女性用トイレでは, 同じ蓄電池 1 本で蓄電池容量の闇值を $86 \%$ 以上とすれば, 50 人にも対応できる.

さらに, トイレ規模の変化が消費と発電にもたらす影響に関して は, 規模増大に伴い照明器具が増加しトイレ利用一回当りの消費量 も増すが単位発電量はトイレ規模に依存しないため, トイレ規模が 大きくなるほどゼロバランスは難くなる，トイレ規模の増大は，単 位消費量に影響する照明器具配置, 誤検知を軽減する動線計画およ び追加洗浄回数が鍵となる.この検討は次に取組むべき課題である.

\section{7. 結}

本研究では, ZET システムを被災大学に適用し, トイレ内の照明 エネルギー収支に与える影響を確認した結果，以下の知見を得た。 1) 男性用卜イレ利用 1 回当りのエネルギー収支は, 消費量 > 発電量 でも, 追加洗浄による発電で, 利用者数と消費量が所定の条件を 満たせれば，照明エネルギー収支はゼロバランスする，すなわち， 収支は利用者数, 振舞い方および自動洗浄回数の関係に依存する. 2) 小便器の利用頻度は, 出入口に一番近い便器が最多で, 出入口に 一番近い小便器の隣は最も少ない. 小便器の利用頻度は, 出入口 からの距離に必ずしも依存せず, 利用者が隣り合わない様に振舞 う傾向が強い。トイレブースの利用頻度も男女問わず, 出入口に 一番近いブースが多く，特に女性用は，その傾向が顕著である。

3）男性用トイレは, 排泄行為を伴わない誤検知が最大 240 回/日あり, 女性用も同様に多い。また, 女性用トイレでは, ブース選択によ る迷いや利用後再確認行動による無駄な検知点灯が散見された。 トイレの平面・機器計画は, エネルギー消費に影響を与える.

4) 男性用トイレは, 出入口の誤検知や利用時の無駄な点灯削減およ び照明点灯のさせ方による削減を組合せることで, 昼光利用が無
い場合でもエネルギー収支ゼロが実現できる見通しを得た。

5）昼光利用や出入口誤検知および無駄な点灯削減を行った結果, エ ネルギーバランス率は大幅に向上した. 昼光利用が有効な手段で あることが確認できた.この傾向は, 女性用トイレも同様である.

6）女性用トイレでは, ブース内の照明点灯による消費量が男性用と 比較して格段に多く, 男女間でブース内での振舞い方に差がある ことが明らかとなった. 女性は使用中連続点灯させる傾向がある.

7）限界利用者数は, 非常時の蓄電池運用条件と蓄電池容量により更 に向上できることを計算により確認した.

今後は, トイレ規模の変化に対応した検証とトイレ内エネルギー 消費に寄与する平面・機器計画手法の提案等を継続する計画である.

\section{謝辞}

本研究にご協力頂いた熊谷力也氏，安尾貴司氏，松田宏氏，山崎 晴生氏，大平雅寛氏，今朋哉氏および児玉崇一氏に謝意を表す.

\section{参考文献}

1) Architectural Institute of Japan: Preliminary Reconnaissance Report of the 2011 Tohoku-Chiho Taiheiyo-Oki Earthquake, 2011.7 (in Japanese) 日本建築学会: 2011 年東北地方太平洋沖地震災害調査速報, 2011.7

2) Itabashi, T. et.al: Diagnosis algorithm of deep vein thrombosis (DVT) medical examination needed at a large-scale disaster, Japanese Association of Medical Technologists, JAMT Vol.66 No.5, pp.449-468, 2017.6 (in Japanese) 板橋匠美, 他 : 大規模災害時に必要とされる DVT 検診の診断アルゴリズ 厶, 医学検查 Vol.66 No.5, pp.449-468, 2017.6

3) Japan Toilet Labo: Toilet of 3.11 The Great East Japan Earthquake, 201 3.3 (in Japanese)

特定非営利活動法人 日本トイレ研究所 : 東日本大震災 3.11 のトイレ-現 場の声から学ぶ-, 2013.3

4) Kato, A. et.al: Toilet and Hygiene Measures for Refuges following an Eart hquake, National Institute of Public Health, Journal of the National Insti tute of Public Health 2010 Vol.59, No.2, pp.116-124, 2010.6 (in Japanese) 加藤篤, 他 : 震災時の避難所等のトイレ・衛生対策, 保健医療科学 2010 Vol.59, No.2, pp.116-124, 2010.6

5) Ishida, T. et.al: Tohoku University Aobayama East Campus Construction Toward Resilient Campus - Part 5 / Total System and Components of ZET, Summaries of Technical Paper of Annual Meeting, Architectural Institute of Japan, Environmental Engineering- II , pp.1085-1086, 2015.9 (in Japanese) 石田壽一, 他 : 東北大学工学部におけるゼロ・エネルギー・トイレ/ZET の 全体構成についてレジリエント・キャンパス構築に関する研究（その 5), 日本建築学会大会学術講演梗概集, 環境工学 II , pp.1085-1086, 2015.9

6) Ishii, H. et.al: Tohoku University Aobayama East Campus Construction Toward Resilient Campus - Part 6 / Outline of Zero Energy Toilet Syst ems regarding zero balance of lighting energy consumption, Summaries of Technical Paper of Annual Meeting, Architectural Institute of Japan, Environmental Engineering- II, pp.1087-1088, 2015.9 (in Japanese) 石井久史, 他: 東北大学工学部におけるゼロ・エネルギー・トイレ/ ZET の全体構成 についてレジリエント・キャンパス構築に関する研究(その 6) ゼロエネ照明システムの 概要，日本建築学会大会学術講演梗概集, 環境工学II, pp.1087-1088, 2015.9

7) Fujiyama, M. et.al: Tohoku University Aobayama East Campus Co nstruction Toward Resilient Campus - Part 7 / Implementation of ZET in the Empirical Location Site, Summaries of Technical Paper of Annual Meeting, Architectural Institute of Japan, Environmenta l Engineering- II , pp.1089-1090, 2015.9 (in Japanese)

藤山真美子, 他: 東北大学工学部におけるゼロ・エネルギー・トイレ/ ZET の全体構成 についてレジリエント・キャンパス構築に関する研究(その7) ZET 実証サイトの整備に つて, 日本建築学会大会学術講演梗概集, 環境工学 II, pp.1089-1090, 2015.9

8) Fujiyama, M. Ishida, T. Kobayashi, H. and Ishii, H.: Study on Zero Energy Lighting System for Toilet Under The Emergency Situation-Verification Experiment at Demonstration Site in Tohoku University-, AIJ journal of Technology and Design. Vol. 22, No.50, pp.281-284, 2016.2 (in Japanese) 


\title{
STUDY ON ENERGY ZERO BALANCE BASED LIGHTING SYSTEM IN TOILET
}

ZET lighting system using the energy harvesting technology implement to actual building

\author{
Hisashi ISHII ${ }^{* 1}$, Mamiko FUJIYAMA*2, Hikaru KOBAYASHI ${ }^{* 3}$ \\ and Toshikazu ISHIDA*4
}

\footnotetext{
${ }^{* 1}$ Senior Research Scientist, Advanced Technology Laboratory, Technology Research Division, LIXIL Corporation, Ph.D.

${ }^{* 2}$ Assist. Prof., Dept. of Urban and Architecture, Graduate School of Engineering, TOHOKU University, Ph.D.

${ }^{* 3}$ Assoc. Prof., Dept. of Urban and Architecture, Graduate School of Engineering, TOHOKU University, Ph.D.

${ }^{* 4}$ Prof., Dept. of Urban and Architecture, Graduate School of Engineering, TOHOKU University, Ph.D.
}

In this study, the energy harvesting system for public toilet was constructed that stores electric energy recovered by micro hydropower generator equipped in tap water supplying pipe into battery. This system uses high-efficiency charge / discharge circuit and Purkinje effect visibility adjusted ultra-high-efficiency LED lighting. ZET system was installed to the toilet of disaster affected Tohoku University and confirmed the influence on the lighting energy balance and excretion behavior by demonstration experiment. As a result the following knowledge was obtained.

1. In the gents' toilet despite that the consumption amount is larger than power generation amount, if the number of users and the consumption amount satisfy the predetermined conditions, the lighting energy of zero balance can be achieved by the power generation of additional flashing for cleaning. That is, the balance depends on the relationship between the number of users, how it behaves, and the number of automatically self-flushing.

2. Regarding the frequency of use of urinal, the closest to the entrance was most frequently used and the fewest were next to the urinal nearest to the entrance. Frequency of use of urinal is not dependent on the distance from the entrance, and there is a strong tendency for the users to act not to be next to each other. Regardless of gender, it was confirmed that toilet booth closest to the entrance were frequently used, especially for Ladies' toilet, the trend is remarkable.

3. Gents' toilet has maximum 240 erroneous detections of LED lighting motion sensor per day without excretory activity, and for Ladies toilets as well. In female toilets, unnecessary detection lights due to lost stances due to booth selection and reconfirmation action after use were found. The toilet plan / equipment plan affects energy consumption of LED lighting.

4. By combining reduction of erroneous detection of entry, reduction of wasteful lighting at the time of use, and controlling how to turn on/off the lighting, the gents' toilet got a prospect that zero energy balance can be achieved even if no daylight use toilet.

5. As a result of utilizing daylight, reduction of erroneous entry detection and wasteful lighting reduction, the energy balance rate of gents' toilet improved significantly. This tendency is the same for ladies' toilet.

6. In ladies' toilet, consumption by lighting in the booth was much larger than that for gents', and it became clear that there is a difference in behavior between male and female. Female tend to turn on the LED lighting continuously during use.

7. Calculation confirmed that the number of maximum capacity of users can be further improved by the storage battery operating conditions and the storage battery capacity in emergency.

In the following research, verification corresponding to changes in the size of the toilet will be continued and both an effective toilet plan and equipment layout methods that contribute to energy consumption will be examined. 